\title{
Litiasis vesical múltiple
}

\author{
Ramón de Fata Chillón F, Martín Osés E, Roque Mir C.
}

Unidad de Urología. Clínica Ruber. Madrid.

Actas Urol Esp. 2007;31(1):64

$\mathrm{P}$ aciente varón de 75 años de edad, con antecedentes de litiasis renal izquierda, que refiere sintomas miccionales del tracto urinario inferior desde hace 7 años en tratamiento médico con alfabloqueantes e inhibidores de la 5-alfa reductasa. $\mathrm{El}$ paciente presenta hace un mes cuadro de retención aguda de orina que requiere sondaje vesical, por lo que es remitido a nuestra consulta.

En la ecografia de aparato urinario se aprecia la presencia de múltiples litiasis vesicales de pequeño tamaño y un volumen prostático de $130 \mathrm{cc}$, PSA: $3,4 \mathrm{ng} / \mathrm{ml}$ y aporta una Urografia Intra-

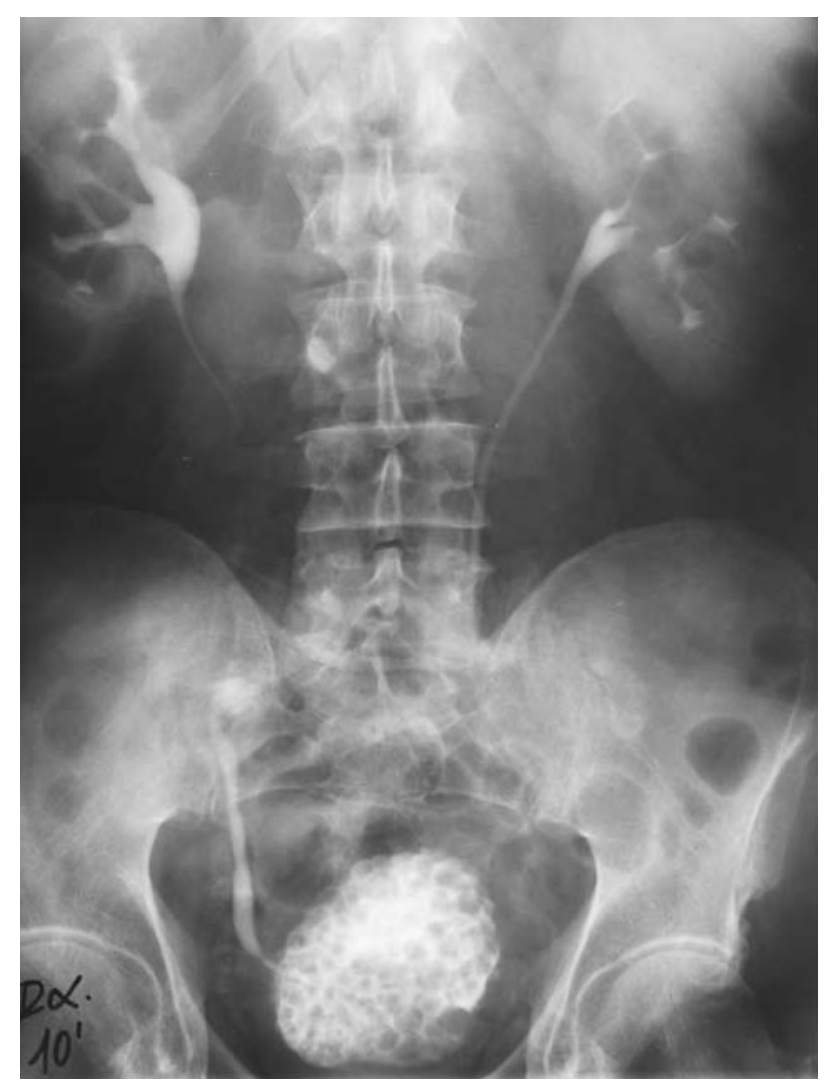
FIGURA 1 venosa realizada en otro centro en la que llama la atención ver una vejiga totalmente ocupada por litiasis de pequeño tamaño (Fig. 1).

Se practicó una Adenomectomía Retropúbica según técnica de Millin con la extracción de 202 cálculos vesicales (Fig. 2).

Correspondencia autor: Dr. F. Ramón de Fata Chillón. Unidad de Urología. Clínica Ruber. Juan Bravo, 49. 28006 Madrid. Tel.: 914026100

E-mail autor: frfata@hotmail.com

Información artículo: Imágenes en Urología

(Trabajo aceptado enero 2006)

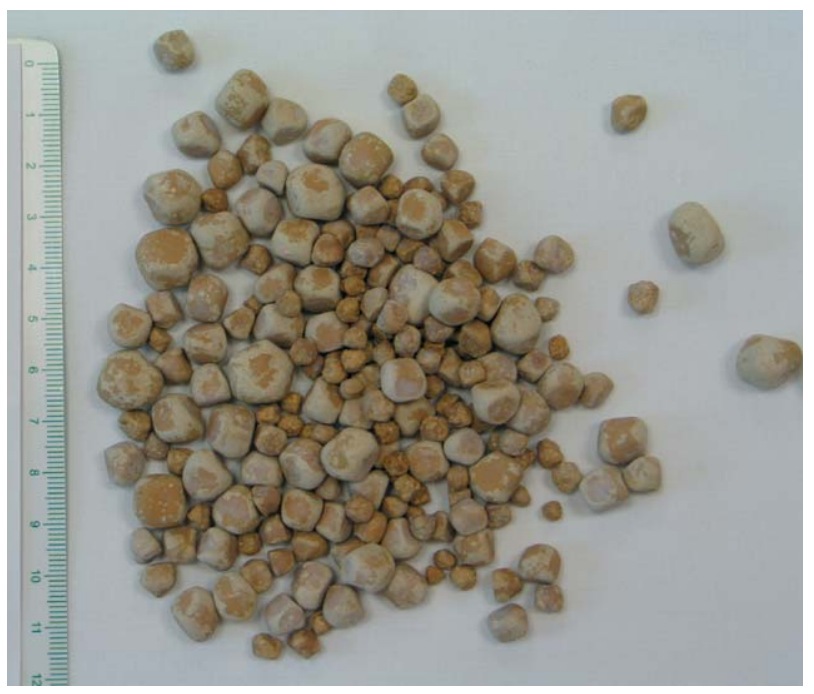

FIGURA 2 